\title{
Locus/Forum Regit Actum - a Dual Principle in Transnational Criminal Matters
}

\begin{abstract}
KRISZTINA KARSA ${ }^{*}$
Abstract. The aim of the paper is to introduce and analyse the binary code of the main principle applied in legal assistance procedures in international criminal matters - the locus regit actum and the forum regit actum sub-principles are characterized by different dynamics and have different legal consequences. While locus regit actum requires the application of the procedural rules of the state that has been addressed with the legal assistance request, the forum regit actum principle asks for application of the requesting state's rules on the given procedure. The result of the legal assistance procedure is the evidence assumed to be used in the criminal procedure to be carried out in the requesting state. The different concepts have very distinguished consequences in the scope of admissibility of the evidence and regarding the legal remedies against obtaining the evidence. Within the European Union, the related developments show a double paradigm shift in this regard - the initial followed locus regit actum was abandoned in 2000 in favour of the forum regit actum, but then in 2017, the member states of the EU opted once again for locus regit actum with the new regime of the European Investigation Order. Finally, the paper highlights the main issues of the concept of the free movement of evidence and shares in addition to positive evaluation, criticism on the subject as well.
\end{abstract}

Keywords: mutual legal assistance, criminal matters, locus regit actum, evidence transfer, recognition

\section{FOUNDATIONS}

In the realm of international cooperation between states, one of the most important questions is determining applicable law whilst satisfying any request received from another state. Especially with regard to cooperation in criminal matters, a dual-face principle has been developed. The states or the different international regulatory frameworks follow one of two fundamentally different approaches: either the locus regit actum or the forum regit actum principle applies to acts in the course of cooperation. After some introductory remarks on the related concepts of this twin-principle, its criminal justice implications will be highlighted, then the double mill of this principle will be examined within the European Union, and finally, some future expectations will be offered for further thoughts based on the latest developments within the EU legal framework (human rights implications and the so-called free movement of evidence).

\footnotetext{
* Professor, University of Szeged, Karsai.Krisztina@juris.u-szeged.hu.
} 
Contextual clarification of the subject requires defining the core concepts accompanying these principles. Legal assistance, often used as mutual legal assistance ${ }^{1}$ is one of the traditional forms of international cooperation in criminal matters besides extradition (surrender within the EU), transfer of proceedings, and transfer of execution (e.g. imprisonment).

Legal assistance is essential in cases with a 'foreign-element': ${ }^{2}$ if any pieces of evidence are linked to foreign countries (in both domestic and transnational cases), legal assistance is the only - democratic and rule of law governed - tool to gather that evidence from abroad. In the course of legal assistance, the state in need requests another state to carry out a specific act or procedure, the result of which would be helpful for the criminal procedure being carried out in the former state. In this context, the state of request is the requesting state, while the other is the requested state. It is important to note that between the Member States (MS) of the EU, the wording has been changed, and we are speaking about issuing MS and executing MS instead of focusing on the request in the professional (linguistic) register. As Vermeulen, De Bondt and Van Damme explained

'the well-known shift from requesting member state to issuing member state and from requested member state to executing member state is not merely symbolic in nature: the mutual recognition concept must turn traditional judicial cooperation - in casu mutual legal assistance - into a more reliable and faster mechanism. ${ }^{3}$

1 Often used as abbreviation MLA.; In different languages, these two words could have different national meanings, but if it is used for describing one of the tools of international cooperation in criminal matters, they can have identical content. However, if the context is beyond European language use - e.g. UN level - the following differentiation shall be made, as it explained by the UN Model Treaty on Mutual Assistance in Criminal Matters: Mutual assistance is not judicial assistance. In civil law countries, and under some other legal systems, investigations are conducted under judicial supervision and are therefore regarded as proceedings even though at the time of those judicially supervised investigations a suspect who has not been arrested may not be aware of the charge against him or her, or even be known. Under the common law heritage, however, the investigation stage is generally conducted by police independent of the judiciary. With rare exception, it is only when the investigation is complete, and the person is charged before a judicial officer that proceedings commence. For countries in which civil law operates and where investigations are judicially supervised, requests for assistance can be made, under this interpretation, even at the investigation stage, by way of letter rogatory from the supervising judicial officer to his or her judicial colleagues in other jurisdictions and can therefore be properly termed 'judicial assistance'. For most common law countries, however, requests cannot be made by a judicial authority during the investigation stage as there is no judicial officer involved until formal proceedings are commenced. Moreover, the term 'mutual assistance' is used in some systems to describe international cooperation generally covering police to police cooperation, extradition, and transfer of prisoners as well. In other states it is considered that the term 'mutual legal assistance' is too limited equating to 'judicial' assistance between judicial authorities only.' http://www.unodc.org/documents/treaties/model_treaty_ extradition_revised_manual.pdf 67 .

${ }^{2}$ For instance: witnesses to be heard are abroad; the evidence is located in the territory of other state; criminal assets have been transferred to foreign country; exchange of judicial information; interrogation of experts; search and seizure, tapping, controlled delivery; exchange of bank information; freezing of bank accounts etc.

3 Vermeulen, De Bondt and Van Damme (2010) 76. 
The dual principle of locus / forum regit actum describes the rules to be applied during the legal assistance procedure: if locus regit actum governs then the procedural rules of the requested (executing) state shall be applied (lex loci); meanwhile forum regit actum principle requires the application of the procedural rules of the requesting (issuing) state (lex fori).

The result of the procedure of legal assistance is evidence that shall cross state borders, and is to be admitted in the requesting (issuing) state by the acting authorities of the concerned states. However, the 'admission as such is not an issue of cooperation'4 is a decision of the judge of the case, who has discretion in this regard, and therefore this is a core issue of admissibility or eligibility, which transforms into a domestic legal-factual question. This means that, without further regard to specific related norms, an initial blindness exists at the time the request is issued as to what the judge will allow to be done with the 'cross-border' evidence. This remains the situation globally, but regionally, European legal efforts aim to cure this blindness and to make legal assistance useful and effective. This development is the concept of free movement of evidence, which concentrates on the admissibility (eligibility) of the 'foreign evidence'; the main links to the examined dual principle will also be addressed later in this paper.

\section{INTERNATIONAL COOPERATION OF STATES IN CRIMINAL MATTERS}

The international cooperation of states is a cooperative work between two sovereign national states that traditionally are not bound to satisfy a request. The international cooperation of states in criminal matters does have its traditions, but the general willingness of states to assist criminal procedures for other states has undergone development since the early 20th century - following the decline of souverains of the empires of the 19th century. In the second half of the $20^{\text {th }}$ Century, especially within Europe, the desire for peace and stability and evolvement of human rights had led to a broad array of multilateral (and bilateral) agreements between states. The individual value of humans as being recognised as subjects of international cooperation (rather than as objects) placed a cornerstone in this development. With the expansion of human rights protection, the law on international cooperation of states was also affected by this development and these can serve to restrict state interests in concrete cases or under specific circumstances. As Parry stated: 'in theory, international human rights play a large role in the erosion of a particular kind of sovereign power. But in practice, most countries continue to have an enormous control over their criminal and penal processes. ${ }^{5}$

The different approach to criminal justice plays a role in how a state behaves towards the requests of another state on legal assistance. As Klimek pointed out: 'the more adversarial the proceedings, the greater the importance normally attached to witnesses appearing in the courtroom and being subject to cross-examination. Evidence obtained abroad by foreign authorities thus becomes less attractive. In inquisitorial systems, where written evidence is more relied upon, the problem is reduced, although there might be concerns that the evidence was not obtained in a required manner. Consequently, common law jurisdictions were traditionally more hesitant than civil law jurisdictions to make use of

\footnotetext{
4 Vermeulen (2006) 41.

5 Parry (2010) 2024.
} 
mutual legal assistance. ${ }^{6}$ Common law countries in particular tend to follow the principle of non-inquiry, which means that the formalities or procedural rules governing the evidencegathering process in the other state are neither questioned nor confirmed at any time; no control is practiced over whether such rules were respected or not. ${ }^{7}$

At the global level, the UN plays an important role in controlling crime, in particular in drug trafficking, trafficking in human beings, combating organised crime, money laundering, and terrorism. The UN conventions establishing regulatory legal frameworks for states against transnational criminality globally include rules on legal assistance (e.g. UN Convention on Transnational Crime, UN Convention against Illicit Traffic in Narcotic Drugs and Psychotropic Substances etc.).

On the UN level, a Model Treaty on Mutual Assistance in Criminal Matters was adopted by General Assembly resolution 45/117 of 14 December 1990 and then underwent revision in 1998. The Model Treaty was formulated to help Member States, enabling them to cope more effectively with criminal cases having transnational implications. As far as possible, it avoids mandatory rules since the penal philosophies and systems of states can and do differ widely. Most issues are regulated by optional rules and it is left to specific bilateral arrangements or multilateral conventions to transform them into mandatory ones, according to the needs and circumstances of inter-state relations. The intent of the Model Treaty was for states, when executing requests for assistance, to provide the widest possible measure of assistance compatible with domestic law or practice. In case of doubt, a requested state should be encouraged to comply with a request. ${ }^{8}$

\section{MUTUAL LEGAL ASSISTANCE IN EUROPE}

The regional European development can be characterized by the raising willingness of the states to help one another in their own criminal cases. The establishment of relevant multilateral and bilateral regulatory framework has therefore raised the intensity of legal assistance requests within Europe in a system-based manner. Mutual legal assistance has become an important pillar of controlling (transnational) criminality jointly. If the states do not hesitate to assist each other in their own criminal investigations and procedures anymore, and if they trust each other in this regard, meaning that the traditional legal and political struggles of cooperation laying in any kind of mistrust are no longer relevant - the benefits of acting transnationally diminish for criminals.

Mutual legal assistance is inevitable since evidence located abroad cannot be gathered by one state on the territory of another state. However, such an option could be a final goal of integrating justice systems as representing unlimited trust between them - this level of trust has not yet been achieved between any MS in the EU.

The European legal development (both Council of Europe and European Union) paints a rather colourful picture concerning the existing institutions of legal assistance; different and independent regimes are operated parallelly often by acknowledging the same scopes of application.

${ }^{6}$ Klimek (2012) 252.

7 Bachmaier (2015) 55, Parry (2010).

$8 \mathrm{http} / / /$ www.unodc.org/documents/treaties/model_treaty_extradition_revised_manual.pdf 69 . 
In Europe, the Council of Europe convention from $1959\left(\mathrm{ECMLA}^{9}\right)$ is the main tool for legal assistance, which was - as Vervaele evaluated - 'worldwide unicum and not an obvious development at that stage as the whole tradition of enforcing criminal law was based on sovereignty and bilateral treaties. The obligation to cooperate is an interstate obligation (comity between states) and the Convention can thus be qualified as an international convention of an administrative-executive nature but dealing with a judicial matter.'10

This 'mother treaty' contained in Article 3 that 'the requested Party shall execute in the manner provided for by its law any letters rogatory relating to a criminal matter and addressed to it by the judicial authorities of the requesting Party for the purpose of procuring evidence or transmitting articles to be produced in evidence, records or documents.'

By categorizing mutual legal assistance, the following prongs shall be considered for comprehensive examination (in Europe):

1. Political discretion or legal automatism: this prong mirrors the understructure of the given legal assistance regime, whether a state keeps this matter under political (diplomatic) control or decides for depoliticization and transfers control for legal ruling (legislation); whether there is room for making a discretional decision or if compliance to an automatic (legally defined) system provides for the execution of the request.

2. Double incrimination: traditionally a state helps another state if its territorial jurisdiction could be hypothetically established, e.g. the requested state would also be able to punish the act committed by the concerned person, had the act been committed in the territory of the requested state. The decision of whether double incrimination / punishability shall be a mandatory requirement for execution of the request is to be balanced under the complex interest matrix of the persons involved, the cooperating states (and in case of the $\mathrm{EU}$, the EU also plays a role in representing common EU criminal policy).

3. Locus regit actum / Forum regit actum: whether the applicable rules of the execution follow locus regit actum or forum regit actum;

a) if the former is followed, what are the conditions for requesting the application of foreign law;

b) if the latter is followed, what are the ground for refusal of the application of foreign law;

4. Extraterritorial execution: whether the act of legal assistance will be carried out by the officials of the requested state or by those of the requesting state within the territory of the other state; or merely whether the officials of the requesting state shall allowed to participate (and maybe observe) in the procedural acts carried out by the hosting officials ('aut exequi, aut tolerare'11).

Van Hoek and Luchtman describe four models of legal assistance in criminal matters in which the different levels of intensity in exercising sovereignty appear. The legal assistance model is the most traditional form. Here, the requested state is free to decide whether to comply with the request (the assistance); in this model the procedural rules of the requested state will be applied. According to the next model, the requested state has to

9 European Convention on mutual assistance in criminal matters. ETS n ${ }^{\circ} 30$ of 20.4.1959.

10 Vervaele (2014) 149.

${ }^{11}$ In analogy to the aut dedere aut exequi principle; tolerating the activity of foreign authorities on the territory is already known and widely accepted in the context of e.g. joint investigation teams. See more Vermeulen, De Bondt and Ryckman (2012) 33. 
satisfy the request and applies its own rules. The third model follows the forum regit actum principle and the fourth model operates with disregard for the territoriality concept, allowing procedural acts to be carried out by foreign officials within the territory of the other state. ${ }^{12}$ These models are legitimate in that they describe the already functioning legal instruments; however, the system is not exhaustive, because further models can be developed through applying the prongs presented. Other categorization has been offered by Vermeulen, De Bondt and Van Damme, the team established six clusters based on the already functioning legal frameworks related to mutual legal assistance (EU and Council of Europe). ${ }^{13}$

\section{MUTUAL LEGAL ASSISTANCE BETWEEN EU MS}

Within the European Union, the objective to establish an area of freedom, security and justice covers the facilitating and accelerating judicial cooperation between authorities in order to be more effective against transnational and cross-border criminality. Issues of mutual legal assistance in criminal matters became important fields of discussion after the third pillar was established as the first instrument declaring (and constituting) judicial and home affairs as matter of common interest for the MS. The complex regulatory framework ${ }^{14}$ has been established through issuing specific norms on legal assistance:

- Convention implementing the Schengen Agreement of 14 June 1985 between the Governments of the States of the Benelux Economic Union, the Federal Republic of Germany and the French Republic on the gradual abolition of checks at their common borders (CISA); $1990^{15}$

- European Convention on Mutual Assistance in Criminal Matters (ECMACM) ${ }^{16}$

- Council Framework Decision 2003/577/JHA of 22 July 2003 on the execution in the European Union of orders freezing property or evidence ${ }^{17}$

- Council Framework Decision 2008/978/JHA of 18 December 2008 on the European evidence warrant for the purpose of obtaining objects, documents and data for use in proceedings in criminal matters ${ }^{18}$

- Directive 2014/41/EU of the European Parliament and of the Council of 3 April 2014 regarding the European Investigation Order (EIO) in criminal matters. ${ }^{19}$

As regards the current legal framework in force, only the European Investigation Order applies for mutual legal assistance within the EU MS, the other instruments listed were replaced by the EIO as of 22 May 2017.

12 van Hoek and Luchtman (2005).

13 Vermeulen, De Bondt and Van Damme (2010) 46-59.

${ }^{14}$ For the analysis and comparison of these instruments see Vermeulen, De Bondt and Van Damme (2010) and Törö (2014).

15 OJ L 239 of 22.9.2000.

16 Convention of 29 May 2000 on Mutual Assistance in Criminal Matters between the Member States of the European Union.' OJ C 197 of 12.7.2000; Council Act of 29 May 2000 establishing in accordance with Article 34 of the Treaty on European Union the Convention on Mutual Assistance in Criminal Matters between the Member States of the European Union OJ C 197 of 12.7.2000.

17 OJ L 196 of 2.8.2003.

18 OJ L 350 of 30.12 .2008 .

19 OJ L 130 of 1.5.2014. 


\section{LOCUS / FORUM REGIT ACTUM WITHIN THE EU LAW}

\subsection{Three Phases and Two Paradigm Shifts}

Based on the acceptance of the examined principles, three stages can be distinguished for the EU MS

\begin{tabular}{|l|l|l|l|}
\hline & from till & applicable law & principle \\
\hline Phase No 1 & $1962-2005$ & ECMLA & locus regit actum \\
\hline Phase No 2 & $2005-2017$ & ECMACM & forum regit actum \\
\hline \multicolumn{2}{|l|}{ infiltrated by other specific instruments } & locus regit actum \\
\hline Phase No 3 & $2017-$ & EIO & locus regit actum \\
\hline
\end{tabular}

Two paradigm shifts characterize the acceptance of the dual principle within the EU. In the beginning, EU MS were applying ECMLA to issues between each other, which meant the application of the locus regit principle. After recognizing the importance of and the need for more intensive cooperation between MS for joint control of transnational criminality, and after establishing the third pillar, intensive negotiations started to create a genuine - and more effective - EU system for legal assistance as well. The MS openness for new legal solutions resulted in ECMACM. ${ }^{20}$ This convention - which was inspired by the Schengen Conventions - followed the genuine new idea, the forum regit actum principle. The innovation was introduced in order to overcome the traditional difficulties and obstacles of legal assistance arising from the nature of locus regit actum. This was the first paradigm shift that had brought along high expectations concerning future success and effectiveness.

After some years of application, it became clear that the innovative instrument opened new gaps that required revision of both the instrument and its regulatory framework in order to be solved. It is important to underline that in the meantime, other crucial developments were launched by the MS, among which the mutual trust concept should be highlighted, and here, the ascending mutual recognition principle should also be referenced. All these circumstances played a role in leading to the decision to opt back to the locus regit actum concept - this constituted the second paradigm shift, the return to the old-fashioned principle of locus regit actum. However, an EU concoction created a unique and genuine regulatory framework around the locus regit actum -the comprehensive instrument of European Investigation Order.

Still the core question remains: should the procedural rules of the requesting- or those of the requested state apply for mutual legal assistance. Theoretically, rules of both countries can be relevant, but - as Törö formulated - a mixture of the different procedural rules provides little support, because the homogeneous and gapless human rights protection of any system could be damaged if only some part (or just single legal institution) were to be applied in a given case. $^{21}$

20 The MS started to apply the convention in 2005.

21 Törö (2014) 134. 


\subsection{Locus Regit Actum - One Step Closer}

The locus regit actum principle is rooted in the sovereignty concept - as mentioned already, by not accepting foreign law in criminal procedures. The principle requires that the procedural acts for gathering evidence be carried out according to the law of the place of act; in the context of the legal assistance this state is the requested state. The application of foreign law is not usual for legal assistance in criminal matters, not even in a procedural sense. The authorities of the requested state carry out the procedural act in their own legal environment and the output of these nationally ruled procedures becomes the result of the request - the evidence assumed to be admitted in the requesting state. However, sometimes this is not so straightforward: the different procedural systems could be lawful and fair in their own legal matrix, whilst at the same time, be formally unlawful in another legal context (e.g.: what kind of warnings will be communicated at the beginning of the hearing; or what type of formalities will be inevitable for accepting the result of expert examination, etc.). This means that the result - which is both formally and substantially lawful in the executing state - may be qualified as formally defective according to laws of the requesting state in case of unidentical procedural rules, which could have the consequence of inability to use the results of legal assistance in a given criminal procedure. If formal 'flaws' prohibit the usage of the evidence, then the entire legal assistance procedure (the request) becomes ineffective and useless, moreover both time-consuming and uneconomical.

The goals of cooperation in criminal matters among MS in the EU aimed to solve the gaps and difficulties that resulted from the locus regit actum principle; therefore, this requires the latter principle to be weakened and broken through and consecutively, the forum regit actum principle will ascend. To overcome these and other similar difficulties and non-results of legal assistance, an innovation was introduced in 2000, the forum regit actum principle with the ECMACM. According to the convention, mutual legal assistance shall be carried out based on the legal norms of the requesting state. Article 4, 1 stated that 'where mutual assistance is afforded, the requested Member State shall comply with the formalities and procedures expressly indicated by the requesting Member State, unless otherwise provided in this Convention and provided that such formalities and procedures are not contrary to the fundamental principles of law in the requested Member State.'

\subsection{Forum Regit Actum - One Step Closer}

Hence, forum regit actum demands the application of the requesting state's law in the course of carrying out the legal assistance, which means that the requesting state defines the norms and procedures to be applied by the executing state. The applied foreign law serves as a guarantee that the result of the legal assistance will (might) be used as evidence in the home procedure of the requesting state. If forum regit actum governs the course of the execution, the executing authority in the requested state shall apply the rules of the requesting state, any reference or complaint afterwards concerning different and noncompatible procedural rules becomes unfounded. Application of the foreign procedural rules aims to ensure that the result of the legal assistance procedure, namely the evidence gathered, will be successfully admitted and used in the criminal procedure of the requesting state. 
International compatibility of evidence-gathering is of growing importance, particularly in view of the control of organized crime. Therefore, the requested procedural and investigative actions should be regarded as an extra-territorial extension of the criminal investigations or procedures conducted within the forum state. ${ }^{22}$

Forum regit actum seemed to be very promising in the negotiation phase and in the first stage of the implementation period - with the expectation that the disadvantages of locus regit actum will be neutralized. Despite this advantageous position, forum regit actum opens more new questions, rather than answering old ones.

Its main shortfall was that it failed to prevent states from excluding the requested evidence (the result of the requested and compiled legal assistance procedure) from the evidence procedure of the requesting state: proceeding courts often oppose the admission of such evidence due to the different (foreign) procedural rules that govern the collection of evidence in the requested state. ${ }^{23}$

Kusak summarized the main flaws of the forum regit actum principle:

a) forum regit actum does not involve a commitment to accepting the admissibility of evidence gathered in accordance with the principle, which means that a request to take certain formalities or procedures into account does not ensure that the effort applied in gathering evidence will be rewarded with admissibility;

b) it has very limited effect on the level of admissibility due to the fact that it applies only in a one on one relationship and has no potential to ensure admissibility within the entirety of the EU;

c) it lacks transparent rules in terms of the lawfulness of the way evidence is gathered;

d) the forum regit actum principle applies only in the case of gathered evidence, meaning that already existing evidence cannot fall within its scope. ${ }^{24}$

By recognizing the fairness and comprehensiveness of this thesis, it shall be added to point a) that neither the locus regit actum principle nor the forum regit actum principle contains expectations or consequences on admissibility or eligibility at all.

In summary, in this regime, the proper application of foreign rules has shown to be extremely difficult as evidenced by practice. In theory, these difficulties could have been eliminated by introducing specific manuals, bilateral trainings, and - to foster the innovation - more intensive integrational tools (e.g. that the officials of the requesting state would carry out the act of the legal assistance within the territory of the other state). But the development in the field of integration of criminal justice systems took another direction: the declaration of mutual trust and the principle of mutual recognition that sprouted up made it obvious that the return to the locus regit actum would be the best option - the complaints, although well-grounded, were discarded with the turnover.

22 Vermeulen (2006) 71.

${ }^{23}$ However, a study proved that such complaints are not so frequent as it was discussed in the negotiations for the reform of the regime of forum regit actum. See more Vermeulen - De Bondt Van Damme (2010) 27: 'Considering the importance of admissibility of the gathered information/ evidence in the course of criminal proceedings in the requesting/issuing member state, several instruments foresee the possibility to expressly indicate that the requested/ordered member state in the execution of the measure, should comply with certain formalities and procedures (e.g. compliance with certain formalities and procedures, purpose or use limitations etc). Interestingly, $60 \%$ (cluster 3 and 5) up to $70 \%$ (cluster 6 ) of the member states indicate to be willing to accept a forum regit actum regime.'

24 Kusak (2019) 394. 
The European Investigation $\operatorname{Order}^{25}$ is once again following the locus regit actum principle and replaces all instruments developed in the field of mutual legal assistance between EU MS.

\subsection{Flanked Principles in Legal Assistance}

The intentional shift back to the locus regit actum had two supporting factors that had not been present at the time of opting for forum regit actum (late 90's). The principle of mutual recognition and the principle of assimilation.

Surely, mutual recognition (and mutual trust) in itself is not yet fully practiced - the regime is fragmented, which means that only selected decisions become subject of mutual recognition, and otherwise MS are often formulating their concerns on specific issues of mutual trust - but the concept and the regulatory framework has been wisely constructed and suitable for the main goals of modernizing and making effective the legal assistance between MS. Mutual recognition as the main pillar of this old-new system provides an initial presumption that the procedural act of legal assistance carried out in the other MS is lawful, fair and complies human rights, therefore any complaint against this presumption should go beyond the foreignness (= not the same rules) of the applied procedural rules, e.g. violation of human rights or concrete breach of law etc.

It is important to note that the principle of assimilation also plays a supporting yet significant role in this regime - if a similar (domestic) procedural act does exist in the legal system of the requested state with regard to legal assistance, the execution of the legal assistance cannot be refused (see the graph).

\subsection{Comparative Approach to the Instruments}

The main features of the instruments discussed here (Council of Europe and European Union) are presented in the following graph.

25 'The EIO Directive appears to be a serious attempt to provide the EU with a modern set of rules for the cross-border transfer of evidence, which is a key aspect of the day-to-day work of practitioners involved in crimes with an international dimension. It balances a streamlined process (such as inclusion of time limits for replying to requests) with a number of important safeguards, as regards the grounds for refusal, the validation of requests from police officers, the proportionality requirement, and the broad list of grounds for refusal, including comparatively string human rights exception.' Peers (2016); See some basic literature: Bachmaier (2015); De Capitani (2016), Schünemann (2014), Ruggeri (2013), Kusak (2019). 
LOCUS / FORUM REGIT ACTUM

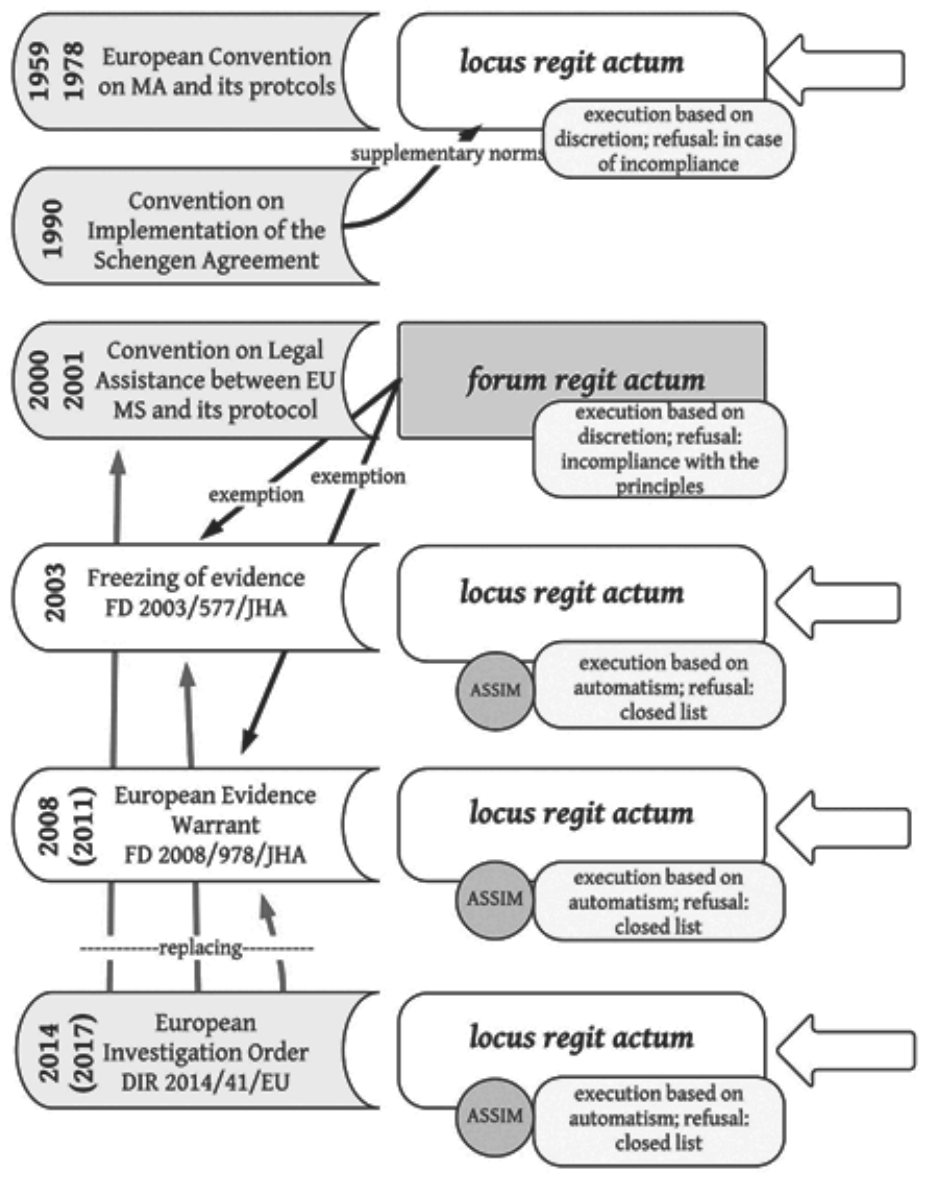

Karsai 2019

application of foreign law
very restricted scope (e.g. oath) application of foreign law if it is necessary for the evidence and is not in contrary with the principles of the other MS

application of foreign law requested formal requirements, if they are not in contrary with the principles of the executing state

application of foreign law requested formal requirements, if they are not in contrary with the principles of the executing

\section{Figure No 1}

The following graph visualizes the locus regit actum / forum regit actum and mutual recognition and mutual legal assistance.

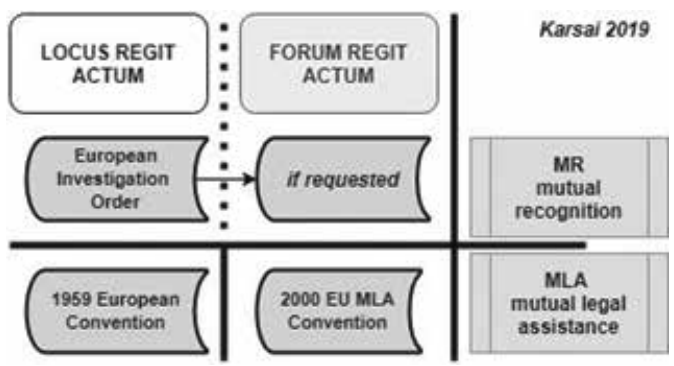

\section{Figure No 2}




\section{HUMAN RIGHTS PROTECTION IN THE COURSE OF LEGAL ASSISTANCE}

The European Court of Human Rights (ECtHR) has jurisdiction on human rights complaints arising in mutual assistance cases. On one hand, because states apply their own law in the course of mutual assistance and the statutory law and their application must comply with the European Convention on Human Rights (ECHR). The states have territorial responsibility to ensure the level of human rights protection flown from the ECHR. On the other hand, states also apply the ECMA (1959), hence the judicature of the ECtHR is highly relevant in mutual assistance cases. ${ }^{26}$ Moreover, if mutual legal assistance will be carried out with third countries, the contracting states of ECHR are obliged to protect the human rights of the concerned persons in extraterritorial issues similarly ('one-way street protection' $)^{27}$. One could argue that although a certain level of confidence does exist between contracting states, this attitude does not necessarily apply toward third countries. However, as Van Hoek and Luchtman highlighted and criticized the 'central role of mutual trust is not reflected by the case law of the ECtHR. In its reasoning the ECtHR often pays specific attention to the question whether the other state involved in the cooperation is or is not a party to the Convention. This would suggest that Contracting States may trust other Contracting States to uphold the Convention rights but may not be so trusting towards nonContracting States. (...) This means that non-Contracting States are not necessarily put to a stricter test when it comes to international cooperation. Conversely, the fact that the other state involved is a Contracting State to the Convention does not relieve a state of its independent duty under the Convention. ${ }^{28}$

Before the adoption of the Charter of Fundamental Rights of the European Union (CFR), EU MS were protecting individuals on their territory by complying with the ECHR (and their own constitutional human rights requirements). The European Court of Justice (ECJ) also played an important role in developing genuine EU protection of human rights, in its jurisdiction already in 1969 the concept appeared according to which fundamental rights became part of the general principles of Community (Union) law and shall be ensured by the ECJ as well. ${ }^{29}$ However, their 'protection' remained fragmented and secondary. This meant that the ECtHR became the main guardian of human rights even in cases where MS were applying national regulatory framework based on Community (Union) law [so ECMLACM (2000) and other relevant EU norms]. It is important to note that EU MS were in some cases arguing before the ECtHR that their - compelled - behaviour is based on EU norms; therefore, ECtHR has no jurisdiction. Although this argument is correct in stating that ECtHR cannot adjudicate on Community (Union) law directly, but as described above,

26 See the latest report on it: Case Law by the European Court of Human Rights of Relevance for the Application of the European Conventions on International Co-Operation in Criminal Matters. Strasbourg, 5.12.2018; PC-OC (2011) 21 REV 12.

27 Van Hoek and Luchtman (2006) 9.

28 Van Hoek and Luchtman (2006) 9.

29 See the case law on it (milestones decisions: Case 29/69 Stauder [1969] ECR 419; Case 11/70 Internationale Handelsgesellschaft [1970] ECR 1125; Case 4/73 Nold [1974] ECR 491. 
the transposed EU norms become part of the national legal system as well, and therefore their application evidently could fall under the jurisdiction of the ECtHR. ${ }^{30}$

The bodies and institutions of the EU have to comply with the CFR by exercising their competences and the Court of Justice of the EU (CJEU) has the right and duty to guard human rights related to the acts of the bodies and institutions of the EU: moreover, it has the competence over MS when they are implementing Union law. Therefore, the release and the application of the CFR opened a new era in this regard as well: the old-fashioned behaviour of EU MS to hide their human rights infringement behind existing EU norms has been terminated.

The CFR does not create any new fundamental right, nor does it extend the scope of the protection already achieved by Union law, but rather, it mirrors the state of art in this regard, but indeed its obligatory character opened a new horizon for enforcing fundamental rights within EU law. Due to the fact that EU law also regulates mutual legal assistance, this means that CJEU - exercising its ordinary jurisdiction - is provided an opportunity to enforce further human rights protection in the course of applying EU-norms of mutual legal assistance. It is my opinion that soon, the first requests for preliminary ruling on the interpretation of the EIO-directive will appear before CJEU. ${ }^{31}$

If locus regit actum governs the course of mutual legal assistance, at the issuing of the request the human rights standards of the requesting (issuing) state will be applied, while during the concrete procedure of the assistance, those of the requested (executing) state shall apply.

Meanwhile, if forum regit actum governs, the law of the requesting (issuing) state rules the entire issue, which means that both the issuing decision and the act of the execution will be carried out only satisfying the standards of the requesting state.

${ }^{30}$ However, in 2005, in the Bosphorus Airways v. Ireland (no. 45036/98) judgment, the ECtHR stated that where a State transferred sovereign powers to an international organisation, absolving contracting states completely from their Convention responsibility in the areas covered by such a transfer would be incompatible with the purpose and object of the ECHR; the guarantees of the ECHR could be limited or excluded at will, thereby depriving it of its peremptory character and undermining the practical and effective nature of its safeguards. For the first time the ECtHR examined on the merits a complaint concerning measures taken to give effect to Community law where the EU MS had no margin of appreciation. See more references: Case-law concerning the European Union, 2019. Factsheet. Published at https://www.echr.coe.int. See some basic literature: Ravasi (2017), DouglasScott (2017).

31 Already happened with the Gavanosov case (C-324-17). The opinion of the Avocat General Bot has been published on $11^{\text {th }}$ April 2019, and the referring Bulgarian court would like to know about the possibility of issuing EIO under national law which does not provide any legal remedy against a court decision issuing a European investigation order (for search) meanwhile the directive in Article 14(2) grants the right to challenge a court decision issuing a European investigation order. In this case the eventual direct effect of the directive could be at stake and furthermore important steps could be made in interpreting definitions of the EIO directive ('concerned party', 'witness', 'third party'). 


\section{FREE MOVEMENT OF EVIDENCE}

\subsection{The Vision}

The vision of free movement of evidences ${ }^{32}$ is footed on smooth cooperation in legal assistance and on the mutual recognition (and mutual trust) principle, and is integrative part of the Area of Freedom, Security and Justice. The Commission has an important role in this regard, representing European criminal policy and triggering innovative steps in European legislation. The establishment of the European Evidence Warrant system was promising in the beginning as mentioned, but its limited applicability highlighted the extreme need for comprehensive solution. The Commission communicated ${ }^{33}$ in 2009 that the establishment of a comprehensive system for obtaining evidence in cross-border cases would be admirable for the MS, and at that time it was already recommended by the Commission (e.g. by experts) to replace the existing legal instruments in this area by a new single instrument which would ensure and facilitate the mutual admissibility of evidence between MS. Almost together with this communication, the Commission published its Green Paper on obtaining evidence in criminal matters from one MS to another and securing its admissibility ${ }^{34}$ and invited the MS to suggest, to debate, and to collaborate to design the free movement of evidence within the EU. The Treaty on the Functioning of the European Union contains a legal basis for EU level legislation, namely according Article 82, 2 'to the extent necessary to facilitate mutual recognition of judgments and judicial decisions and police and judicial cooperation in criminal matters having a cross-border dimension, the European Parliament and the Council may, by means of directives adopted in accordance with the ordinary legislative procedure, establish minimum rules. Such rules shall take into account the differences between the legal traditions and systems of the Member States. They shall concern: (a) mutual admissibility of evidence between Member States (...).' This means that the legal basis for establishing minimum rules in this regard has been created, if gaps remained by the governance of locus or forum regit actum principle then the minimum standards 'supranational' legislation could be a valid and effective option to move forward toward. However, this step was not necessary because the MS decided to turn back: the EIO opened a new chapter in this regard (as already evaluated as the second paradigm shift) with the return to locus regit actum principle, the procedural rules of the other MS continue to remain the main subject of mutual recognition. This can ensure that the formal admissibility will no longer be contested in a concrete case and that the national standards of other MS for gathering evidence must be subject of doubt.

32 Mentioned for the first time by the Tampere Council Resolutions, in 1999; as following: ' 36. The principle of mutual recognition should also apply to pre-trial orders, in particular to those which would enable competent authorities quickly to secure evidence and to seize assets which are easily movable; evidence lawfully gathered by one Member State's authorities should be admissible before the courts of other Member States, taking into account the standards that apply there.' Some basic literature: Klimek (2012), Ruggeri (2014), Vervaele (2014).

33 Communication from the Commission to the European Parliament and the Council: An area of freedom, security and justice serving the citizen - COM(2009) 262.

${ }^{34}$ COM (2009) 624 final. 


\subsection{Unlawfully Obtained Evidence}

Mapping the connections of forum/locus regit actum to other not less important issues of European criminal law, and furthermore, the treatment of unlawfully obtained evidence shall be addressed. As mentioned above, the dual principle examined in this paper has no conceptual element in this regard and it has also been demonstrated that nowadays the exclusion of evidence - based on solely formal 'flaws' between EU MS - is no longer an option. However, material 'flaws' (in particular any act of legal assistance containing human rights violation) could result in unlawfully obtained evidence. Now, the question remains as to how locus and forum regit actum in the very specific context of unlawfully obtained evidence and its admissibility should be interpreted. Kusak identified the varying theoretic approaches to the issue:

- relying on lex locus legislation and using foreign requirements with regard to admissibility of evidence;

- relying on lex forum legislation and using the same model of control that applies to evidence gathered nationally;

- limiting the domestic model of control to general principles, such as the legal order or fundamental rights;

- ignoring both the foreign and domestic models of control and automatically recognising the evidence as regular. ${ }^{35}$

Vermeulen, De Bondt and Van Damme highlighted a very interesting phenomenon that provides a solid basis for further organic integration in this field. After the analysis of evidence rules on unlawfully obtained evidence in the MS, they found that the greatest differences exist in member states when it comes to the value that they attribute to unlawfully obtained evidence in further stages of the criminal justice process. Not only is there a great variety among member states as to the use of unlawfully obtained evidence in a merely national context as steering or supportive evidence or the complete exclusion thereof, but some variation also exists as to the value that member states attribute to this evidence in a national context on one hand, and on the other hand, to this evidence when it is obtained from abroad. While some member states attribute the exact same value to unlawfully obtained evidence in a national context and when it comes from another member state, others do show some difference in the validation of foreign evidence. Some member states are stricter in the validation of unlawfully obtained evidence from another member state, and surprisingly, sometimes more leniency is shown in this validation of foreign evidence. The fact that a significant number of member states already make no distinction in the validation of unlawfully obtained evidence as to where it was obtained is definitely a sign of the possibility of future complete mutual admissibility of evidence, and attributing the same value to any kind of evidence, no matter where in the EU it was obtained. Furthermore, in most member states all of these rules are governed by statutory law, only a small fraction of these embedded rules are constitutionally ingrained. This could mean that the future harmonization of rules for mutual admissibility of evidence would not necessarily pose major legal problems for a large majority of member states. ${ }^{36}$

35 Kusak (2019) 29.

36 Vermeulen, De Bondt and Van Damme (2010) 32. 
In the context of the current regime of EIO, it can be expected that the standards of the executing MS will govern the identification and assessment (adjudication) of human rights violations during the execution of legal assistance (of the EIO), and the concerned person can request protection in that country (or before the ECtHR against that country). However, it cannot be excluded that in the issuing state a complaint will be lodged because of the human right violation - actually, if the suspicion of the violation arises or the violation will be discovered in time e.g. after receiving the result of the legal assistance (EIO).

\subsection{Beyond the Admissibility - Harmonization (?) of the Level of Belief}

However, the final aim of any legal assistance is that the judge will indeed use the evidence for conviction or acquittal; for the adjudication of the case. But it is obvious that judges are free and independent to accept evidence gathered and obtained according to (any) law. As mentioned before, the admissibility of evidence reaches far beyond the locus and forum regit actum principle, but the issue of mapping their conceptual connections is permanently addressed in this paper as well. It seems to be impossible to establish a system where the 'material admission' is provided e.g. the judge will surely use the evidence gathered abroad. The reason is simple and evident: adjudication is both a human decision-making process and a result of thereof, where the judge has to develop his or her own belief on the facts of the given criminal case (based on the conclusive evidence) and has to conclude to convict or acquit (based on cognitive multi-processes). Legal knowledge is also required but only for legal qualification and not to be convinced about the facts. Frontline legal practitioners report on the phenomenon that a set of proven facts that could serve for conviction (or for acquittal) could be very divergent in the different MS (in comparable cases). This means that different judges might need different levels of probability to assume the facts to be proven or to be convinced about the commission of the crime, and in other words, the same or comparable set of evidence would lead to firm belief in one country would not necessarily bring the same results in another. Different legal culture and professional socialization, different levels of independence of the judiciary (for example: how broad is the revisional power of the higher courts), and the general approach to criminal justice are among the reasons for this phenomenon. Comparing only the probability beyond reasonable doubt with the probability of the objective truth, the obviosity of this argument is uncovered. The importance of this issue can be highlighted by referring to the forum shopping phenomena exercised by law enforcement authorities or prosecutors: after successfully cooperating in a joint investigation team, MS are allowed to decide which country will carry out the criminal procedure, it is obvious and not contested that aspects of evidence law or the evidentiary practice of the courts of the concerned MS play an important role in deciding about the place of adjudication (in which MS it will takes place). I am convinced that the next step of the integration is to work on this issue through research and comparative analysis.

\section{CONCLUDING REMARKS}

Enforcing European territoriality will erase the importance of the discussion of locus or forum regit actum in enhancing cooperation and integration within the field of criminal justice. If common European norms will govern the field of gathering and taking evidence, and the specialities (differences) will be subject of recognition, the fact on the origin of the procedural rules will no longer be relevant. Until this happens, MS work in this multileveled system of designed under a cooperative legal framework and give their best in guaranteeing 
human rights through their own constitutional rules as well, where both legal discrepancies and judicial mechanisms that counterbalance them (in particular by CJEU) are also part of the bigger picture.

Nowadays sometimes we think that this development - how to make different procedural systems compatible with one another - is something similar as we would like to send a tram on a railway... According to the vision of professionals and academia, it has become clear that this is the best path leading to a bright future (e.g. to the effective and fair combat against criminality). The existence of very new legal instruments supports the vision of being blind of the consequences of the dual principle of forum / locus regit actum, thus are incompatible with the binarity of locus/forum regit actum principle (especially joint investigation teams). Furthermore, a significant number of investigative measures still do exist which are not explicitly regulated but are applied mutually by the MS. ${ }^{37}$ In such cases, locus or forum regit actum is per se inexplicable. 'Nevertheless, assistance for those investigative measures remains possible based on the obligation to afford each other the widest possible measure of assistance.'

At the end of the day, we managed to link the railway with the tram successfully. ${ }^{38}$

\section{OPEN ACCESS}

This is an open-access article distributed under the terms of the Creative Commons Attribution 4.0 International License (https://creativecommons.org/licenses/by/4.0), which permits unrestricted use, distribution, and reproduction in any medium, provided the original author and source are credited, a link to the CC License is provided, and changes - if any - are indicated. (SID_1)

\section{LITERATURE ${ }^{39}$}

Bachmaier, Lorena, 'Transnational Evidence. Towards the Transposition of Directive 2014/41 Regarding the European Investigation Order in Criminal Matters' (2015) 2 Eucrim, The European Criminal Law Association's Forum 47-58.

De Capitani, E, Peers, Steve; 'The European Investigation Order: A new approach to mutual recognition in criminal matters' Eulawanalysis (January 8, 2016) http://eulawanalysis.blogspot. $\mathrm{pt} / 2014 / 05$.

Douglas-Scott, Sionaidh (ed.), Research handbook on EU law and human rights (Elgar Publishing, 2017) 211-309.

Klimek, Libor, 'Free movement of evidence in criminal matters in the EU' (2012) 4 The Law Quarterly 250-90.

Kusak, Martyna, 'Mutual admissibility of evidence and the European investigation order: aspirations lost in reality' (2019) 19 ERA Forum 391-400.

Parry, John T., 'International extradition, the rule of non-inquiry and the problem of sovereignty' (2010) 90 Boston University Law Review 1973-2029.

37 Vermeulen, De Bondt and Van Damme (2010) 17

38 The reference goes to the project of Szeged City (Hungary) on the seamless transition from an inner-city tram-trip to a regional train journey between Szeged and Hódmezővásárhely.

39 This research was carried out in the project no. EFOP-3.6.2-16-2017-00007, entitled 'Aspects on the development of intelligent, sustainable and inclusive society: social, technological, innovation networks in employment and digital economy', supported by the European Union, co-financed by the European Social Fund and the budget of Hungary. 
Peers, Steve, EU Justice and Home Affairs Law. Volume II: EU Criminal Law, Policing and Civil Law (Volume II, Oxford 2016) 115-250.

Ravasi, Elisa, Human rights protection by the ECtHR and the ECJ. A comparative analysis in light of the equivalency doctrine (Brill 2017) 143-389.

Ruggeri, Stefano (ed.), Transnational Inquiries and the Protection of Fundamental Rights in Criminal Proceedings (Springer 2013) 27-40; 241-310.

Törő, Andrea, Bizonyíték-transzfer az európai bűnügyi együttmüködésben - különös tekintettel az európai nyomozási határozatra [Transfer of evidence in the European cooperation in criminal matter with special regard to the European Investigation Order]. (2014 University of Szeged, Manuscript).

Schünemann, Bernd, 'The European Investigation Order: A Rush into the Wrong Direction' in Ruggeri, Stefano (ed) Transnational Evidence and Multicultural Inquiries in Europe (Heidelberg, N.Y., 2014) 29-35.

van Hoek, Aukje A.H. and Luchtman, Michiel J.J.P., 'Transnational cooperation in criminal matters and the safeguarding of human rights'. (2005) 2 Utrecht Law Review 1-39.

Vermeulen, Gert, 'EU conventions enhancing and updating traditional mechanisms for judicial cooperation in criminal matters' (2006) 77 Revue internationale de droit pénal 59-96.

Vermeulen, Gert, De Bondt, Wivian and Van Damme, Yvonne, EU cross-border gathering and use of evidence in criminal matters. Towards mutual recognition of investigative measures and free movement of evidence? (Maklu 2010) 43-126.

Vermeulen, Gert, De Bondt, Wivian and Ryckman, Cryer (eds), Rethinking international cooperation in criminal matters in the EU. Moving beyond actors, bringing logic back, footed in reality (Maklu 2012) 105-386.

Vervaele, John A.E., European Criminal Justice in the Post-Lisbon Area of Freedom, Security and Justice (Università degli Studi di Trento 2014) 139-66. 